\title{
ASPECTE IMUNOLOGICE ÎN AFECT,IUNILE ADENOAMIGDALIENE PEDIATRICE
}

\author{
A. Zamfir-Chiru-Anton', D.C. Gheorghe ${ }^{2}$

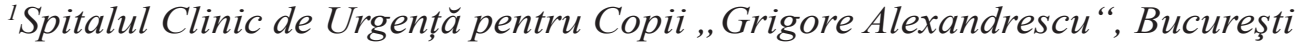 \\ ${ }^{2}$ Spitalul Clinic de Urgență pentru Copii ,, M.S. Curie“, \\ Universitatea de Medicină şi Farmacie „, Carol Davila“, Bucureşti
}

\begin{abstract}
REZUMAT
Mecanismele fiziopatologice ale hipertrofiei adenoizilor şi amigdalelor rămân incomplet elucidate, dar numeroasele studii clinice au demonstrat că procesele proliferative din cadrul amigdalitelor hipertrofice obstructive comparativ cu cele din amigdalitele cu recurențe infecțioase sunt reglate diferit, sugerând procese fiziopatogenice diferite.

Studierea aspectelor imunologice ne permite desluşirea etiopatogeniei şi, implicit, abordarea prin intermediul unor căi terapeutice specifice a afecțiunilor acestor organe limfoide cu impact important atât asupra funcțiilor cardiovasculare şi neurologice, cât şi asupra comportamentului copilului.
\end{abstract}

Cuvinte cheie: amigdalita la copii, răspuns imun

În cadrul afecțiunilor respiratorii la copii ce țin de sfera otorinolaringologiei, o frecvență relativ mare, în procent de 1-3, este reprezentată de apneea obstructivă în somn (1). Apneea obstructivă în somn reprezintă o afecțiune caracterizată prin episoade repetate de oprire a respiratiei în timpul somnului, cu hipoventilație, hipoxemie şi hipercapnie decelabile (2). Cauzele pot fi reprezentate de obezitate, pe de o parte, şi de efectul obstructiv exercitat de hipertrofia adenoamigdaliană, pe de altă parte (3). Amigdalele palatine reprezintă un organ de primă linie în apărarea gazdei fiind efectori ai sistemului umoral, dar şi ai imunității celulare, dar pot reprezenta şi un focar pentru procesele inflamatorii recurente.

Referitor la severitatea şi prognosticul episoadelor de apnee în somn demonstrate prin polisomnografie, trebuie să amintim de clasificarea lui Michael Friedman (4). Aceasta cuprinde o stadializare clinică luând în considerare poziția palatului, gradul de hipertrofie a amigdalelor şi indexul de masă corporală. Totodată, scorul Friedman are şi o valoare predictivă a severității sindromului de apnee în somn. Astfel:

- Stadiul I - este reprezentat de poziția palatului I (la bucofaringoscopie permite vizualizarea uvulei şi amigdalelor) sau II (la bucofa- ringoscopie se vizualizează doar uvula) combinată cu o hipertrofie amigdaliană de tip III (amigdale extinse în afara pilerilor, dar care nu ating linia mediană) sau IV (amigdalele se unesc la nivelul liniei mediane);

- Stadiul II - este definit prin poziția palatului III (la bucofaringoscopie se vizualizează doar palatul moale, dar fără observarea luetei şi a palatului dur) sau IV (la bucofaringoscopie se vizualizează doar palatul dur) combinată cu hipertrofia amigdaliană de tip III sau IV;

- Stadiul III - palatul este în poziție I, II sau III asociat cu hipertrofie amigdaliană de tip 0 , I (amigdale intravelice) sau II (amigdalele se extind puțin dincolo de marginea pilierilor).

Se consideră că toți pacienții cu indice corporal mai mare de 40 se încadrează în stadiul III.

Numeroase studii clinice realizate pe culturi celulare prelevate de la nivelul vegetaţiilor adenoide şi amigdalelor hipertrofice, culturi celulare care mimează fidel condițiile din vivo (5), subliniază rolul inflamaţiei în etipatogenia hipetrofiei adenoamigdaliene din apneea în somn, dar şi din recurențele infecțioase ale amigdalelor hipertrofice. Asfel, s-a demonstrat existența unor expresii diferite ale răspunsului imun la copiii cu hipetrofie limfoidă obstructivă, manifestate prin concentrații ale recep-

Adresa de corespondență:

A. Zamfir-Chiru-Anton, Spitalul Clinic de Urgență pentru Copii „Grigore Alexandrescu“, Bd. lancu de Hunedoara, nr. 30-32, Sector 1, Bucureşti

E-mail: zamfiradina@yahoo.com 
torilor pentru leucotriene (CysLTR1 şi CysLTR2) mai mari decât la pacienții cu recurențe infecțioase (6). Acest fapt a explicat eficiența clinică a terapiei cu antagoniști ai receptorilor pentru leucotriene (precum Monteleukast-ul) în hipertrofiile amigdaliene, cu ameliorări semnificative ale episoadelor de apnee în somn (7).

Totodată, s-au studiat receptorii pentru glucocorticoizi la nivel tonsilar atât la copiii cu boală obstructivă a amigdalelor, cât şi la cei cu recurențe infecţioase amigdaliene (8). S-au remarcat concentrații mult mai crescute la copiii din prima categorie, explicând astfel eficiența administrării cortizonului local (intranazal) la pacienții cu apnee în somn (9).

Alte cercetări au urmărit bazele moleculare implicate în răspunsul imunitar al amigdalelor palatine față de antigeni, evidențiind rolul MIF în procesul inflamației. Aceasta este o protează, asociată axului hipofizo-hipotalamo-adrenalian care ar putea constitui o țintă medicamentoasâ, în scopul scăderii răspunsului imunitar la antigene, în țesuturile amigdalian şi adenoidian (10). Aceeaşi substanţă inhibă efectele glucocorticoizilor. Alți autori au raportat concentrații ridicate de MIF la pacienții cu apnee obstructivă în somn, asociind nivelele sale cu severitatea clinică a bolii (11).

Reactiile alergice pot contribui la apariția hipertrofiei adenoidiene şi/sau amigdaliene. Unele studii au inclus pacienți cu alergii alimentare dovedite, în căutarea unei posibile asocieri a hiperreactivității la caseină, alfa-lactalbumină, beta-lactoglobulină (12, 13) sau ovalbumină cu răspunsul alergic al mucoaselor respiratorii. Epitopii alergenilor sunt legați specific de către imunoglobulinele de tip IgE, IgG4 şi IgA. Reacția inflamatorie consecutivă legării specifice a $\operatorname{IgE}$ se corelează cu tipul alergenului. Toleranța față de un antigen specific poate apărea şi poate duce la o scădere a reacției inflamatorii, în timp. Din contră, IgG4 își mențin specificitatea legării la epitopi neschimbată, de-a lungul timpului. Din acest motiv, ele pot oferi toleranță alergică față de unele antigene, prin legarea lor competitivă la aceleaşi fracțiuni peptidice ca şi $\operatorname{IgE}(14)$. Aceste informații ar putea duce la obținerea unor markeri de prognostic sau la dezvoltarea unor protocoale terapeutice noi, prin creşterea nivelului de IgG4 specifice, protectoare, la anumiți pacienți (15).

Alte studii au dozat IFN $\alpha, \operatorname{IFN} \gamma, \operatorname{IgA}, \operatorname{IgG}, \operatorname{IgE}$ în saliva pacienților cu amigdalită cronică şi au identificat subpopulațiile de limfocite în țesutul obținut prin biopsie prelevat din amigdale prezentând infecții cu EBV, HPV, CMV diagnosticate şi confirmate prin PCR (16). Formele de amigdalită compli- cată cu reacții toxico-alergice au dovedit insuficiența factorilor de protecție IgG şi o creştere a IgE. Pentru managementul amigdalitelor cronice s-au imaginat terapii de substituție care utilizează anticorpi (imunoglobuline pentru administrare intravenoasă). S-a mai discutat posibilitatea corectării imunităţii prin administrarea de IFN $\alpha$, IFN $\gamma$ şi preparate bazate pe lizate bacteriene. Deja există studii publicate despre o asociere directă între nivelurile de IFN-gamma şi celulele Th2 implicate în reacțiile inflamatorii $(17,18)$.

Studiul molecular al dermatitei atopice s-a concentrat pe enzimele implicate în dezintegrarea barierelor epiteliale (19). Au fost descrişi receptori activați de proteinaze (PAR 1 şi PAR2), cu roluri critice în răspunsul pro/antiinflamator al mucoaselor respiratorii (20). Activarea lor determină secretia de IL1 şi IL8, urmată de o permeabilitate vasculară crescută şi un răspuns leucocitar local. Celulele $\mathrm{T}$ prezentatoare de antigen inițiază reacția inflamatorie şi activează celulele Th2. Urmează rapid secreția de IFN-gamma, IL3, IL4, IL9 şi IL13 şi activarea mastocitelor, eozinofilelor şi bazofilelor. Celulele dendritice epidermice produc IL1, IL6 şi TNF-alfa. În evoluție, inflamația poate trece într-o formă cronică dacă IL12 și IL18 sunt secretate, urmate de un răspuns imun prin celule Th1 (21).

Răspunsul imun mediat prin celulele Th1 este intens și inițial generat de concentrații mari de IFNgamma şi TNF-alfa. Ulterior apare o reacție imună cu formare de anticorpi (mediată prin Th2), mai puțin intensă şi ca o consecinţă a acumulării de IL6 şi IL4. IL6 prezintă nivele mari în țesuturile amigdaliene, iar IL4 predomină în sânge (22).

Alte aspecte ale procesului inflamator au fost cercetate. Th1 şi IFN-gamma pot inhiba producția de Th2 (23). Aceeaşi acţiune o are şi IL18(24). Levamisolul, un antihelmintic, poate ameliora simptomele de rinită alergică la şoareci prin creşterea nivelelor de IL18 (25).

TNF-alfa este o citokină proinflamatorie şi o chemokină pentru granulocite. Secreția sa poate fi stimulată administrând peptide de tip ovalbumină recombinată (sau alergeni similari). Rolul său poate fi demonstrat prin terapia cu anticorpi monoclonali (Infliximab, care scade producerea de TNF-alfa şi răspunsul alergic mediat de Th2 (26).

SHP-1 este un regulator proteic al căilor Th2 dependente (18). Este un modulator important la nivelul căilor aeriene inferioare şi superioare. Se leagă la receptorii IL4 şi îi inactivează, modificând astfel răspunsul imun mediat Th2. Luând în considerație şi celelalte funcții ale IL4 (stimularea eozinofilelor, mastocitelor, diferențierea celulelor Th2, 
creşterea abilității macrofagelor de a prezenta antigenul, diferențierea celulelor B) se poate deduce importanța rolului reglator al proteinei SHP-1 în reactia inflamatorie.

Din punct de vedere histopatologic, în amigdalele hipertrofice epiteliul este îngustat, nu există granițe bine delimitate cu tesutul limfoid de sub epiteliul de suprafață. Foliculii limfoizi sunt măriți, cu centri germinativi hiperplazici care prezintă o zonă marginală subțire. Țesutul interfolicular este redus. În tonsilitele cu infecții recurente, epiteliul de suprafață este subțiat prezentând câmpuri de keratină. Subepitelial, foliculii limfoizi sunt mici, cu centri germinativi bine delimitați şi zona marginală distinctă. În zona extrafoliculară există fibroză, iar la nivelul criptelor amigdaliene există detritusuri celulare.

În amigdalita de tip obstructiv sunt descrise creşteri în dimensiuni ale foliculilor, ce implică un număr mare de celule limfoide existente la nivelul centrilor germinativi. Astfel, în cazul copiilor cu apnee în somn s-a evidențiat proliferarea masivă a limfocitelor de tip $\mathrm{T}$ şi totodată niveluri scăzute ale celulelor limfocitare de tip B, în timp ce în cazul recurențelor infectioase adenoamigdaliene predomină răspunsul celular cu limfocite de tip B. Concentrația receptorilor celulelor B şi T (cysteinyl LT) la aceşti pacienți este foarte variată. S-a discutat despre posibilitatea folosirii acestor receptori ca ținte medicamentoase în cazurile de hipertrofii amigdaliene obstructive (7).

Mastocitele sunt distribuite în regiunile interfoliculare şi perivasculare. Sunt mai des întâlnite în țesutul amigdalian al pacienților alergici, în raport cu subiecții sănătoşi. Activarea lor pare să fie mediată de CD4+ (celule Th2) (27).

Unele studii au dozat concentraţia citokinelor în sângele periferic şi s-a constatat că nu există diferențe majore între cele două tipuri de amigdalite (hipertrofice obstructive versus amigdale cu recurențe infecțioase). În timpul răspunsului inflamator, la nivel tonsilar, IFN $\gamma$ este prezent într-o concentrație de 3-5 ori mai mare decât în cazul hipertrofiei obstructive. Aceasta sugerează un deficit în activarea sistemului imun mediat prin limfocitele T-helper (alterarea populației de limfocite $\mathrm{T}$ circulante, cu creşterea concentrației citokinelor proinflamatorii IL6, IFN $\gamma$, TNF $\alpha$, concomitent cu scăderea citokinelor antiinflamatorii - IL10). Totuşi, în ambele tipuri de afecțiuni amigdaliene, producția de citokine mediate prin limfocitele Th1 (TNF $\alpha$ şi IFN $\gamma$ ) este mai mare decât cea mediată prin intermediul limfocitelor Th2 (IL6 şi IL4) rezultând predominanța răspunsului imun celular faţă de cel umoral
(22). Recent, s-a descoperit o subgrupă de celule T helper denumite Th17 care produc citokine de tip IL17 (proinflamatorii) şi care se dezvoltă diferit de limfocitele Th1 şi Th2, având rol în imunitatea antimicrobiană (28).

Streptococul grup A (GAS) a fost multă vreme indicat drept cauza principală a amigdalitelor recurente. Unele studii au cercetat procesul de imunizare împotriva acestei bacterii, folosind ovalbuminGAS (bacterii prezentând un epitop proteic similar ovalbuminei pe suprafața lor) (27). Celulele CD4+ (celule T) au mediat reacția imună. Activarea lor a fost observată în mucoasa nazală, sau în ganglionii limfatici şi splină, în funcție de calea utilizată la administrarea antigenului. Când prezentarea antigenului a fost nazală, au fost înregistrate niveluri mari de CD4+, IL17 şi IFN-gamma local. Sistemul imun nu dezvoltă o protecție de durată contra streptococului grup A după o primă/unică infecție. Reacția imună este de scurtă durată, mediată Th17(29). Pentru a induce un răspuns imun durabil, este necesară o producție prelungită şi repetată de Th17 de către celulele CD4+ (30). Implicațiile acestui fenomen rămân a fi descoperite.

Afinitatea streptococului pentru țesutul amigdalian poate fi consecința nivelelor ridicate de TGFbeta şi IL6, la unii pacienți.

Terapia imunologică specifică ar trebui să adreseze 2 mecanisme:

- Blocarea celulelor care prezintă antigen T;

- Stimularea producției de IgG4 şi inhibarea mastocitelor, eozinofilelor şi IgE.

Mecanismele necesare pentru a obține aceste deziderate şi desensibilizarea sunt creşterea nivelelor de IL10 şi TGF-beta. De asemenea, terapia specifică cu imunoglobuline pentru celule $\mathrm{T}$ ar trebui să influențeze activitatea $\mathrm{Th} 2$ şi producția de $\operatorname{IgE}$ şi să influențeze crească valorile IgG4 (31).

Există şi studii care au cercetat concentrațiile de IL6 şi IL8, în ambele tipuri de amigdalite. IL8 a fost crescută în boala recurentă, iar IL6 (împreună cu IFN-alfa) în formele de boală hipertrofică (5). Studii genetice au demonstrat o asociere între polimorfismul genei pentru IL6 şi prezența unor amigdale palatine obstructive (32).

Comparativ cu hipertrofia amigdaliană de tip obstructiv, în tonsilitele recurente, la suprafața epiteliului tonsilar s-a evidențiat un grad mare de fibroză şi o densitate mare a limfocitelor cu memorie (CD45R0+), limfocitelor B (CD20+), limfocitelor T citotoxice (CD8+) (33). De asemenea, densitatea imunoglobulinelor IgG, IgA, IgM şi TNF- $\alpha$ la nivelul criptelor a fost semnificativ mai mare, fapt explicat printr-o reacție inflamatorie puternică ge- 
nerată de persistența antigenelor bacteriene. Răspunsul imun mediat de limfocitele T helper (Th1) este bazat pe diferențele dintre concentrațiile locale ale TNF $\alpha$ şi IL4. Se justifică leziunile la distanță de focarul amigdalian prin răspunsul imun anormal manifestat prin supraexpresia limfocitelor $T$ (CD8+) combinată cu cu expresia scăzută a PD-1 (programmed cell death-1) şi FOXp3 (fork head box protein-3) (34).

\section{CONCLUZII}

Cunoaşterea mecanismelor răspunsului imun care apare diferențiat în funcție de factorul trigger ne permite dezvoltarea unor terapii noi, țintite atât pentru boala cercetată, cât şi pentru prevenirea recidivelor. Deşi departe de o înțelegere perfectă, mecanismele moleculare complexe implicate în hipertrofia limfoidă şi infecția amigdaliană cronică ar putea permite rezolvarea mai eficientă a unei patologii orl pediatrice foarte vechi. 